races of Turkey, perhaps with the connivance of Russia, to seek its own welfare regardless of the general convenience of Europe.

EDWARD Channing.

\section{THE LATEST SLIDES IN THE WHITE MOUNTAINS.}

THE great slide of July 10, upon the north slope of Cherry mountain, has been described in Science, July 31. Since then others have been revealed at various localities, but particularly at Waterville. Upon August 13, the rainfall was excessive in that township. The fields and hillsides about Elliot's hotel were completely flooded and Mad River rose twenty or thirty feet. It transpired shortly afterwards that the famous slide upon the south side of Tripyramid had been renewed and enlarged, and that upon the north side of the same elevation its double had made its appearance. This last one is not visible from any of the White Mountain localities much visited, unless it be from the distant summit of Mount Washington. I had the pleasure of visiting both these slides September 10, in company with several gentlemen and ladies from the hotel. We walked up the northern slide first, ascended the north peak of Tripyramid, followed the ridge to the south peak and then descended the old slide to its base in 'Beckytown.'

Four slides converge into one at the upper end of the northern stream. Two of them are too precipitous to be travelled over with safety. Each of these tributaries may be about a half mile in length, while the united stream below is about a mile long. Its course lay entirely through the primitive forest, and it did not reach so far as Norway brook by a half mile. An immense pile of tree-stumps and roots marks its lower extremity. The ledges exposed are mostly of gabbro. From north Tripyramid one can see that the slides upon the westside of Mount Lowell-the old Brickhouse Mountain-have also been in motion the present season.

The old slide of Tripyramid started October 4, 1869 , in that wonderful rainstorm which cost the state of New Hampshire between one and two millions of dollars for repairs. It has been fully described in the 'Geology of New Hampshire.' The first steep slope amounts to three-fourths of a mile, then the current bends at a right angle and flowed to Beckytown, a further distance of more than two miles, where the trees were deposited which marked the end. The new slide takes up nearly three times as much space at the beginning, but the flood was less abundant below the bend. During the sixteen years since the first catastrophe bushes had grown over the base ground. Those were rot quite all removed by the last floods, showing it to be less extensive.

The freshet which moved the bowlder from the Flume in Lincoln (Franconia) three years since seems to have been more powerful than any of this season's slides.

C. H. HitchCOCK.

\section{AN HONOR TO AMERICAN OPTICIANS.}

Through the courtesy of Messrs. Alvan Clark \& Sons, we are able to publish the following extract from a letter written to them by Dr. Otto Struve :

"I am asked by the government to inform you that, in acknowledgement of the excellent performances of the great object-glass, furnished for Pulkowa by your firm, his majesty, the Emperor, has been graciously pleased to confer upon you the golden honorary medal of the Empire. The value of this gift is enhanced by the circumstance that this medal is given very rarely and only for quite extraordinary merits. You and Repsold are the first who will receive it from the present Emperor, Alexander III.

"This circumstance produces some delay in the transmission, as the Emperor desires that the medal shall bear his portrait, and not that of his predecessors. Therefore the stamp must be newly engraved. When that be done, you will receive the medal through the Russian minister at Washington.

"When this letter reaches you I shall be on a journey through Germany and Switzerland. First I shall assist at the general meeting of the Astronomical association, at Geneva, and then must go for a cure to the well-known watering place, Carlsbad. Though my health is tolerably good at this moment, I feel still very tired, and from the illness of last winter there is left some affection that demands serious treatment.

"You will be pleased to hear that, with the 30inch refractor in good nights all the most difficult double-stars, discovered by Burnham with the Washington refractor, can be easily measured. During the last weeks, Hermann has collected already some hundreds of measures on similar objects that were out of the reach of the old 15-inch refractor. . . . OTTO StRUVE."

Pulkowa, July 23.

\section{WEST AFRICAN ISLANDS.}

MAJOR ELLIS, known as the author of ' West African sketches' and other works, accumulated the notes from which this volume was prepared, 